\title{
Analysis on the Integrated Teaching Mode of Economic Management Major in Colleges and Universities
}

Xin Liu

Xuchang University, Xuchang 461000, Henan, China.

Abstract: The integrated teaching mode of economic management major in colleges and universities combines the advantages of traditional teaching and modern teaching, and brings students a new learning experience, which is conducive to improving the teaching quality of economic management major in colleges and universities in China. This paper focuses on the discussion for "the advantages of integrated teaching mode for economic management majors in colleges and universities" and "analysis of integrated teaching mode of economic management majors in Colleges and universities". It is hoped that through the integration of teaching modes, the teaching reform of economic management majors in colleges and universities in China can be better promoted.

Keywords: Colleges and Universities; Economic Management; Professional Integration; Teaching Mode

Economics and management are closely related to real life. With the development of the society, the major of economic management in colleges and universities in China also needs to be reformed. "Integrated teaching mode" has rich connotation and advocates the strong combination of traditional teaching and modern teaching. The use of integrated teaching mode can not only enrich teachers' teaching resources, but also broaden students' learning path. With the practice of the integrated teaching mode, the economic management major in China's colleges and universities has entered a new stage of development.

\section{Advantages of integrated teaching mode for economic management majors in colleges and universities}

\subsection{Stimulating students' interest in learning}

In the teaching of economic management major in colleges and universities, students' interest in learning is greatly stimulated by the integrated teaching mode. Specifically, on the one hand, in the teaching of economics and management majors, the traditional teaching mode has a great dependence on the teaching materials, and teachers mainly teach according to the teaching materials. Under the integrated teaching mode, the learning content that students are exposed to is more abundant, which have a lot of connection with real life, so as to be conducive to stimulate students' interest in learning; On the other hand, in the teaching of economics and management majors, the traditional teaching mode is to take teachers as the core and lead, and teachers' narrative teaching occupies most of the classroom time ${ }^{[1]}$. In the integrated teaching mode, students' subject consciousness for learning can be well stimulated, so that they can actively discover, explore, solve and innovate problems in the process of class. It is because of the strengthening of students' participation, students' interest in learning will be gradually ignited.

\subsection{Improving the teaching efficiency for teachers}

In order to build an efficient economic management class classroom, we should pay attention to improve the teaching

Copyright $(2020$ Xin Liu

doi: $10.18686 /$ ahe.v4i10.2900

This is an open-access article distributed under the terms of the Creative Commons Attribution Non-Commercial License (http://creativecommons. org/licenses/by-nc/4.0/), which permits unrestricted non-commercial use, distribution, and reproduction in any medium, provided the original work is properly cited. 
efficiency of teachers. Under the integrated teaching mode, the teaching efficiency of teachers is obviously improved. Firstly, in the teaching of economics and management majors, through the integrated teaching mode, teachers can re-optimize the teaching system, design the teaching process, and divide the teaching into two parts: "teaching outside the classroom" and "teaching in the classroom", so as to effectively expand the second classroom of economic management major and improve the overall teaching efficiency of teachers; Second, in the teaching of economic management majors, with the help of integrated teaching mode ${ }^{[2]}$, teachers can use information-based teaching tools, integrate online teaching resources, and create diversified teaching situations, so as to bring new learning experience to students. In this process, information-based teaching tools are convenient and efficient, saving teachers' blackboard writing time and teaching time, so that teachers can have more time to answer questions, interact and expand, which is conducive to improving the teaching efficiency of teachers in the classroom.

\subsection{Cultivating innovative ability for students}

With the increasing popularity of quality education, improving students' innovation ability is an important part of the practice of education and teaching reform in colleges and universities in the new period. Under the integrated teaching mode, economic management majors in colleges and universities can better cultivate students' innovative ability. On the one hand, in the teaching of economic management major, teachers can carry out rich and colorful teaching activities by using the advantages of integrated teaching mode, which can change the traditional economic management class and inject new vitality into the classroom. In such a learning atmosphere, students can diffuse their thinking and be unconsciously influenced to form a good sense of innovation through extensive communication, team cooperation and teachers' guidance. On the other hand, in the teaching of economic management majors, teachers use the advantages of integrated teaching mode, arrange "extracurricular expansion task" and "social practice task", in order to encourage students to carry out innovative learning in their spare time, and consciously cultivate students' innovative ability.

\section{Analysis on the integrated teaching mode of economic management major in colleges and universities}

\subsection{Establishing an efficient economic management class by reasonable use of "micro class"}

In the teaching of economic management major in colleges and universities, "micro class" is a typical teaching method in the integrated teaching mode. Through the reasonable use of micro class, we can better optimize the course structure and establish an efficient economic management class. Specifically, on the one hand, in the teaching of economic management majors, teachers can make "economic management professional preview micro class" to guide students to carry out targeted preview before class. Through the preview before class, students can be familiar with the learning content in class, which is convenient for students to have in-depth interaction with teachers in class, and improve the learning effect of students in the classroom; on the other hand, in the teaching of economic management major, teachers can make "economic management major and difficult knowledge micro class" to provide differentiated guidance for students with different learning basis. Moreover, the micro class has the characteristics of short, accurate and easy to spread. Students can learn micro class on mobile phone, breaking through the limitation of time and space. Based on the network attribute ${ }^{[3]}$, micro lesson can also be used as a kind of long-term learning material, which is convenient for students to consolidate and review regularly.

\subsection{Enriching the teaching situation of economic management major by scientific use of "multimedia teaching"}

In the integrated teaching mode, "multimedia teaching" is a widely used teaching method. After the adoption of multimedia teaching, the teaching of economics and management major in colleges and universities is more abundant and changeable. Specifically speaking, first, in the teaching of economic management majors, multimedia teaching can present more abundant teaching resources, such as financial knowledge, tax knowledge, accounting knowledge, financial management knowledge, etc. students can open a broader vision in the limited time. Moreover, teachers can make mind maps for key and difficult knowledge. For example, many knowledge of economic law of accounting major involves "enterprise operation". In this way, the students are clear at a glance and strengthen their learning and memory for the different branches, such as tax law, bill law and enterprise law; Second, in the teaching of economics and management majors, multimedia teaching can present 
text, pictures, audio, video and other contents simultaneously, creating a "three-dimensional" learning situation, so that students are more willing to accept the information conveyed by teachers. For example, there are many labor dispute cases involved in accounting professional economic law knowledge. Teachers can play relevant case videos, and then throw questions to arouse students' thinking and discussion ${ }^{[4]}$. In such a teaching situation, students' thinking is more active and more likely to produce cognitive resonance.

\subsection{Innovating the teaching of economics and management by using MOOC to expand teaching content}

"MOOC" refers to a large-scale online teaching. In the integrated teaching mode, the use of MOOC to expand the teaching content can well innovate the teaching of economics and management majors in colleges and universities. Specifically, on the one hand, in the teaching of economics and management majors, the time in class is very limited, so teachers can list "MOOC review guide" to guide students to carry out special review in MOOC. For example, when learning the economic law knowledge of finance major, teachers can list "MOOC review guide" from the perspective of "foreign exchange management system", "Securities Law" and "Banking Law", so that students can carry out consolidated learning in their spare time; on the other hand, in the teaching of economic management major, the cases are always different, and the situation is very complicated, therefore, teachers should start from the "mode of thinking", focus on cultivating students' innovative thinking, so that students can flexibly analyze and solve complex economic and management problems. Teachers can arrange "MOOCS to expand learning tasks" and encourage students to expand learning content and innovate problem-solving paths in the way of autonomous learning. For example, in the knowledge related to labor law, some enterprises will "force layoffs". At this time, how to protect their rights involves many details. Taking this as a starting point ${ }^{[5]}$, teachers can gradually stimulate students' innovative thinking.

\section{Conclusion}

Practice has proved that through the integrated teaching mode, not only can improve the teaching quality of economic management major in colleges and universities, but also can fully stimulate students' interest in learning, so that students can regain the confidence and enthusiasm of learning in the economic management class. It is worth noting that the integrated teaching mode is only a kind of teaching method and teaching idea. In the specific application of the integrated teaching mode, teachers should base on the actual situation and flexibly carry out integrated teaching, instead of blindly pursuing formalism and ignoring the actual needs of students.

\section{References}

1. Xing J, Wang H, Liu Y. Classroom cultivation of enterprising consciousness for college students majoring in economics and management. Education and Teaching Forum 2018; (49): 50-51.

2. Wang Y. Research on practical teaching mode of economic management major, management and technology of small and medium sized enterprises(Mid day Journal) 2018; (11): 125-126.

3. Zhang R. Research on the teaching integration of information technology and economic management discipline. Science and Technology Style 2018; (32): 61.

4. Xiao S. Countermeasures and analysis of economic management teaching in higher vocational colleges under the background of the new era. Modern Economic Information 2018; (12): 431.

5. Cheng X. An attempt to embed MOOC into traditional classroom teaching. Educational Modernization 2018; (13): $232-234$.

6. Yan T. Exploration of hybrid teaching mode based on cloud class. Higher Education in China 2018; (17): 58-59. 